Journal of Educational Method and Technology Vol. 2 No. 2, Agustus 2019

P-ISSN 2622-8459 E-ISSN 2622-8467

http://ejournal.unima.ac.id/index.php/jemtec

\title{
Education Values In Novel Madogiwa No Totto-Chan By Tetsuko Kuroyanagi
}

\author{
H M L Pandi ${ }^{1}$ \\ ${ }^{1}$ Universitas Negeri Manado, Indonesia \\ corresponding author: ${ }^{1}$ helenapandi@unima.ac.id
}

\begin{abstract}
This study aims to gain an in-depth understanding of educational values in the novel Madogiwa No Totto-chan by Tetsuko Kuroyanagi with a qualitative approach that includes educational values in terms of the structure of the novel. Research methods. This research is a library research or library research that uses a qualitative approach with content analysis techniques. Conclusion of research findings: The main theme of this novel is EDUCATION, education that frees students to be creative, while the sub-theme is education must be adjusted to the development of the child's personality. The credentials found are: A mother must be wise in educating and caring for her children with special needs. A school principal or a teacher should be a leader who is brave to act in accordance with their respective beliefs and life principles. The educational values in this novel can be used as examples of learning in schools to help children with problems (special needs). An educator should be fun and not scold his students because educating children is not with anger but with advice, praise, and trust. Make kids confident, responsible, love each other, and help each other, introduce them to nature because nature stores various sources of knowledge. Educational values found are educational values related to religious education values, moral education values, social education values, and beauty education values. Recommendation: Madogiwa No Totto-chan's autobiographical novel (Totto-chan Little Girl in the Window) can be used as a learning tool for character education in schools in Indonesia because this Japanese novel has raised educational values that contain a number of noble values. One of the noble values is the value of education in the novel that abstracts the reality of Japanese society's life. Education in Japan can be applied to education in Indonesia.
\end{abstract}

Keywords: Novel; Educational Values

\section{Introduction}

Teaching appreciation of novels in general can take an important role in helping young people develop themselves to become superior human beings. According to Sumardi, "teaching appreciation of literature (novels) can support the achievement of good language and literary teaching. The next effect, good language 
and literary teaching plays a role in developing quality national education. The final impact is that quality national education can produce superior young people ". Regarding character education as one of the contents of the 2013 curriculum, Sumardi further said that reading novels can provide several benefits as follows: 1 . Being superior nutrition for the development of the right hemisphere brain. 2. Give / offer healthy entertainment. 3. Provide / offer healthy human values. 4. Able to train readers to develop imagination and creativity. 5. Can train the reader to develop the ability to concentrate. 6 . Able to foster reading pleasure.

One of the novels that raised about educational values is the novel Madogiwa No Totto-chan (Little Girl Totto-chan in the Window). Madogiwa No Totto-chan is an autobiographical novel written by Tetsuko Kuroyanagi. The novel Madogiwa No Totto-chan tells the story of Kuroyanagi's past who was fondly called Totto-chan as a child. Totto-chan is a naughty child and difficult to be accepted in public schools. Since being expelled from his old school, he was transferred to a new school called the Tomoe School. Tomoe School was the first place he met the Principal of the Sosaku Kobayashi, who was finally able to make many changes in his life and his friends. Totto-chan's friends who also have personality problems are Takahashi-kun and Oe-kun. Takahashi-kun is a child who has perfect physical growth and has a sense of self-confidence while Oe-kun is a naughty child and does not appreciate his friend Tomoe School is a school that was built at the same time headed by the Principal of the Sosaku Kobayashi School. Principal Kobayashi applies a different method of education from other schools. He applies free and independent teaching methods. This method can make children develop in their own way without coercion from others. Every child brings good character and personality when born into the world. There are various kinds of impacts caused by environmental influences and the bad effects of adults in their growth. Therefore, Sosaku Kobayashi strives to find that good character and personality so that children can grow to become distinctive personalities. The Principal of Kobayashi School is also a very pleasant educator and never scolds his students because according to him educating children is not with anger but with advice, praise, and trust. The Principal of the Kobayashi School makes children confident, responsible, loving towards each other, and helping each other. He also forms a variety of children's characters and always introduces them to nature because according to him nature stores various sources of knowledge. The novel Madogiwa No Totto-chan applies many appropriate educational methods in educating children. By paying attention to the educational methods applied by the Principal of Kobayashi we can take an example of how to achieve optimal educational goals. Everything that is used to educate must contain student values, including in media selection. Literary work is a structure. Structure here in the sense that the work is a composition of systemic elements, which between the elements occur reciprocal relationships, mutually determine. So, the unity of the elements in literature is not just a collection or a pile of things or objects that stand alone, but they are interrelated, and interdependent Novel as a literary work, which is a work of art also requires consideration and judgment about the art. The novel Madogiwa No Totto-chan (Little Girl Totto-chan in the Window), is a work that contains a number of sublime values. One of them is the educational value in a novel that illustrates the reality of Japanese society's life. Based on the background of the problem above, the 
Journal of Educational Method and Technology Vol. 2 No. 2, Agustus 2019

P-ISSN 2622-8459 E-ISSN 2622-8467

http://ejournal.unima.ac.id/index.php/jemtec

researcher is interested conducted a study entitled "Educational Values in the Novel Madogiwa No Totto-chan by Tetsuko Kuroyanagi".

\section{Research Focus and Subfocus}

The focus of this research is "Educational Values in the Novel Madogiwa no Tottochan" by Tetsuko Kuroyanagi, while the research subfocus of Education Values is reviewed in the structure of the novel Madogiwa No Totto-chan.

\section{Formulation of the problem}

1. How are the educational values described by the author in the novel Madogiwa No Totto-chan? :

2. How are Educational Values viewed from the structure of the text in the novel Madogiwa No Totto-chan?

\section{Research Methodology}

\section{Research objectives}

Obtaining a deep meaning about educational values in terms of the structure of the text in the novel Madogiwa No Totto-chan.

\section{Place and Time of Research}

This research is a library research that is not bound by a particular place.

\section{Research Background}

The setting of this research is Madogiwa No Totto-chan's novel by Tetsuko Kuroyanagi, published by the publisher of PT Gramedia Pustaka Utama in Jakarta in 2009. The novel has 271 pages. The cover of the novel is white, with a picture of a little girl in a brown hat, also wearing brown shoes.

\section{Research Methods and Procedures}

The approach used in this research is a qualitative approach with content analysis techniques. This type of research is library research. As for what is meant by library research is to make library materials in the form of books, scientific magazines, documents and other material that can be used as a reference source in this study.

Furthermore, in analyzing researchers using the approach commonly used in the science of literature that is genetic structuralism approach, namely research that not only originates from the text itself autonomously but also originates from factors outside the literary text (extrinsic), namely the study of literary contexts outside the text.

Content analysis is used to uncover the values of education and combining the structural text and the social context of society.

\section{Data and Data Sources}

Data collected for this study are data obtained through structural descriptions (themes, figures, characterizations, plot, settings, intention / purpose), followed by data on educational values related to religious education values, moral education values, values social education, and the value of beauty education. 
The data source is primary data, namely Madogiwa No Totto-chan's novel by Tetsuko Kuroyanagi and secondary data obtained from heuristic novel readings, theories, writings related to Madogiwa No Totto-chan's novel. This secondary data is used to support the interpretation of primary data.

\section{Research Results}

Data Summary of Novel Research Structure Results Table

\begin{tabular}{|l|l|l|}
\hline \multicolumn{2}{|c|}{ Theme Table } \\
\hline Main Theme & \multicolumn{1}{|c|}{ Sub Theme } & \multicolumn{1}{c|}{ Information } \\
\hline $\begin{array}{l}\text { Education; } \\
\text { education that } \\
\text { frees students } \\
\text { personality }\end{array}$ & $\begin{array}{l}\text { Education must } \\
\text { be adjusted to the } \\
\text { tevelopment of } \\
\text { pe }\end{array}$ & $\begin{array}{l}\text { The method of learning in the Tomoe } \\
\text { School is free and independent. In this } \\
\text { case students are free to start lessons } \\
\text { according to the lessons they like and } \\
\text { are free to ask the teacher if there are } \\
\text { things they do not understand. }\end{array}$ \\
& $\begin{array}{l}\text { Studying at Tomoe School is not only } \\
\text { focused on formal education, but } \\
\text { rather balances academic education } \\
\text { with personality development. }\end{array}$ \\
& $\begin{array}{l}\text { The educational method at Tomoe } \\
\text { School has many positive effects on } \\
\text { the personality development of } \\
\text { students, as well as Totto-chan, } \\
\text { Takahashi-kun, and Oe-kun who } \\
\text { initially experienced problems in their } \\
\text { personalities. }\end{array}$ \\
\hline
\end{tabular}

\begin{tabular}{|l|l|l|}
\hline \multicolumn{1}{|c|}{ Character and characterization table } \\
\hline Totto chan & $\begin{array}{l}\text { Characterization } \\
\text { Aggressive, brave, } \\
\text { curious }\end{array}$ & $\begin{array}{l}\text { Information } \\
\text { Totto-chan is the first main } \\
\text { character in the novel Madogiwa } \\
\text { No Totto-chan. Totto-chan's real } \\
\text { name is Tetsuko Kuroyanagi. }\end{array}$ \\
$\begin{array}{l}\text { Sosaku } \\
\text { Kobayashi }\end{array}$ & Patient, authoritative & $\begin{array}{l}\text { Sosaku Kobayashi is the second } \\
\text { main chacter. He is the } \\
\text { principal and at the same time } \\
\text { the founder of Tomoe Gakuen } \\
\text { and the Japan Eurithmic }\end{array}$ \\
\hline
\end{tabular}


http://ejournal.unima.ac.id/index.php/jemtec

\begin{tabular}{|c|c|c|}
\hline \multicolumn{3}{|c|}{ Character and characterization table } \\
\hline Character & Characterization & Information \\
\hline & & Association. \\
\hline Akira Takahasi & Patient, gregarious & $\begin{array}{l}\text { Takahashi-kun or Akira } \\
\text { Takahashi is the first subordinate } \\
\text { character. He is a male student } \\
\text { who has imperfect body growth. }\end{array}$ \\
\hline $\begin{array}{l}\text { Miyo Kaneko } \\
\text { (Miyo-Chan) }\end{array}$ & Friendly, kind & $\begin{array}{l}\text { Miyo-chan is the second } \\
\text { subordinate character. She is the } \\
\text { third daughter of the principal of } \\
\text { the Kobayashi school. }\end{array}$ \\
\hline $\begin{array}{l}\text { Sakko } \\
\text { Matsuyama } \\
\text { (Sakko-chan) }\end{array}$ & Lively, kind & $\begin{array}{l}\text { Sakko-chan is the third } \\
\text { subordinate character. She is a } \\
\text { girl with wide eyes and likes to } \\
\text { wear clothes decorated with } \\
\text { rabbits. }\end{array}$ \\
\hline $\begin{array}{l}\text { Taiji Yamanouchi } \\
\text { (Tai-Chan) }\end{array}$ & $\begin{array}{l}\text { Quiet, serious, and } \\
\text { smart }\end{array}$ & $\begin{array}{l}\text { Tai-chan is a smart student who } \\
\text { likes physics and likes to do } \\
\text { science experiments. }\end{array}$ \\
\hline $\begin{array}{l}\text { Kunio Oe (Oe- } \\
\text { kun) }\end{array}$ & $\begin{array}{l}\text { Naughty and nosy to } \\
\text { friends in class }\end{array}$ & $\begin{array}{l}\text { Oe-kun is the biggest and fatest } \\
\text { male student in the class. Oe-kun } \\
\text { is a child who is naughty and } \\
\text { rude to girls. }\end{array}$ \\
\hline $\begin{array}{l}\text { Kazuo Amadera } \\
\text { (Amadera) }\end{array}$ & Serious and smart & $\begin{array}{l}\text { Amadera, a student who loves } \\
\text { animals, aspires to be a } \\
\text { veterinarian and farmland. }\end{array}$ \\
\hline Aiko Saisho & Funny & $\begin{array}{l}\text { Aiko Saisho is a companion } \\
\text { character for Totto-Chan's } \\
\text { friend. }\end{array}$ \\
\hline $\begin{array}{l}\text { Keiko Aoki } \\
\text { (Keiko-chan) }\end{array}$ & Funny and gregarious & $\begin{array}{l}\text { Keiko-chan is a supplementary } \\
\text { character. He is a female student } \\
\text { who has a chicken that can fly. }\end{array}$ \\
\hline
\end{tabular}


http://ejournal.unima.ac.id/index.php/jemtec

\begin{tabular}{|l|l|l|}
\hline \multicolumn{1}{|c|}{ Character and characterization table } \\
\hline \multicolumn{1}{|c|}{ Character } & \multicolumn{1}{c|}{ Characterization } & \multicolumn{1}{c|}{ Information } \\
\hline $\begin{array}{l}\text { Yoichi Migata } \\
\text { Migata-kun) }\end{array}$ & Good and gregarious & $\begin{array}{l}\text { Migita-kun a male classmate } \\
\text { with Totto-chan he always } \\
\text { promised to bring a cake when } \\
\text { he returned to his village }\end{array}$ \\
$\begin{array}{l}\text { Yasuaki } \\
\text { Yamamoto }\end{array}$ & Quiet and smart & $\begin{array}{l}\text { Yasuaki-chan is a child who has } \\
\text { physical disorder due to } \\
\text { suffering from polio. }\end{array}$ \\
Ryo-Chan & $\begin{array}{l}\text { Good and like to help } \\
\text { children }\end{array}$ & $\begin{array}{l}\text { Ryo-chan, gardener in Tomoe, } \\
\text { is an adult, but they always call } \\
\text { him by his childhood calls. } \\
\text { Because he was an adult, he was } \\
\text { sent to go to war. }\end{array}$ \\
Miyazaki & Good and smart & $\begin{array}{l}\text { Miyazaki is a tall, well-built } \\
\text { female student for boys at her } \\
\text { age. He was born and raised in } \\
\text { America Miyazaki is good at } \\
\text { English, he often teaches his } \\
\text { classmates }\end{array}$ \\
\hline
\end{tabular}

\begin{tabular}{|l|l|}
\hline \multicolumn{2}{|c|}{ Plot table } \\
\hline $\begin{array}{l}\text { Chronological } \\
\text { plot }\end{array}$ & $\begin{array}{l}\text { Information } \\
\text { The plot used in the Madogiwa No Totto-chan novel is a } \\
\text { forward plot. The story starts from the beginning and } \\
\text { ends at the end. The initial stage of the Madogiwa No } \\
\text { Totto-chan novel is the character Totto-chan who is } \\
\text { considered naughty by teachers in his old school expelled } \\
\text { from school because it often causes chaos when lessons } \\
\text { are taking place. Then he was moved by Mama to a } \\
\text { natural school called Tomoe School which only used the } \\
\text { train cars as a study room. At the end of the story, Japan } \\
\text { at that time was in turmoil because of the Second World } \\
\text { War, many bomb attacks were dropped through American } \\
\text { military aircraft. Tomoe's school was burned and } \\
\text { destroyed. Since that incident life at the Tomoe School }\end{array}$ \\
\hline
\end{tabular}




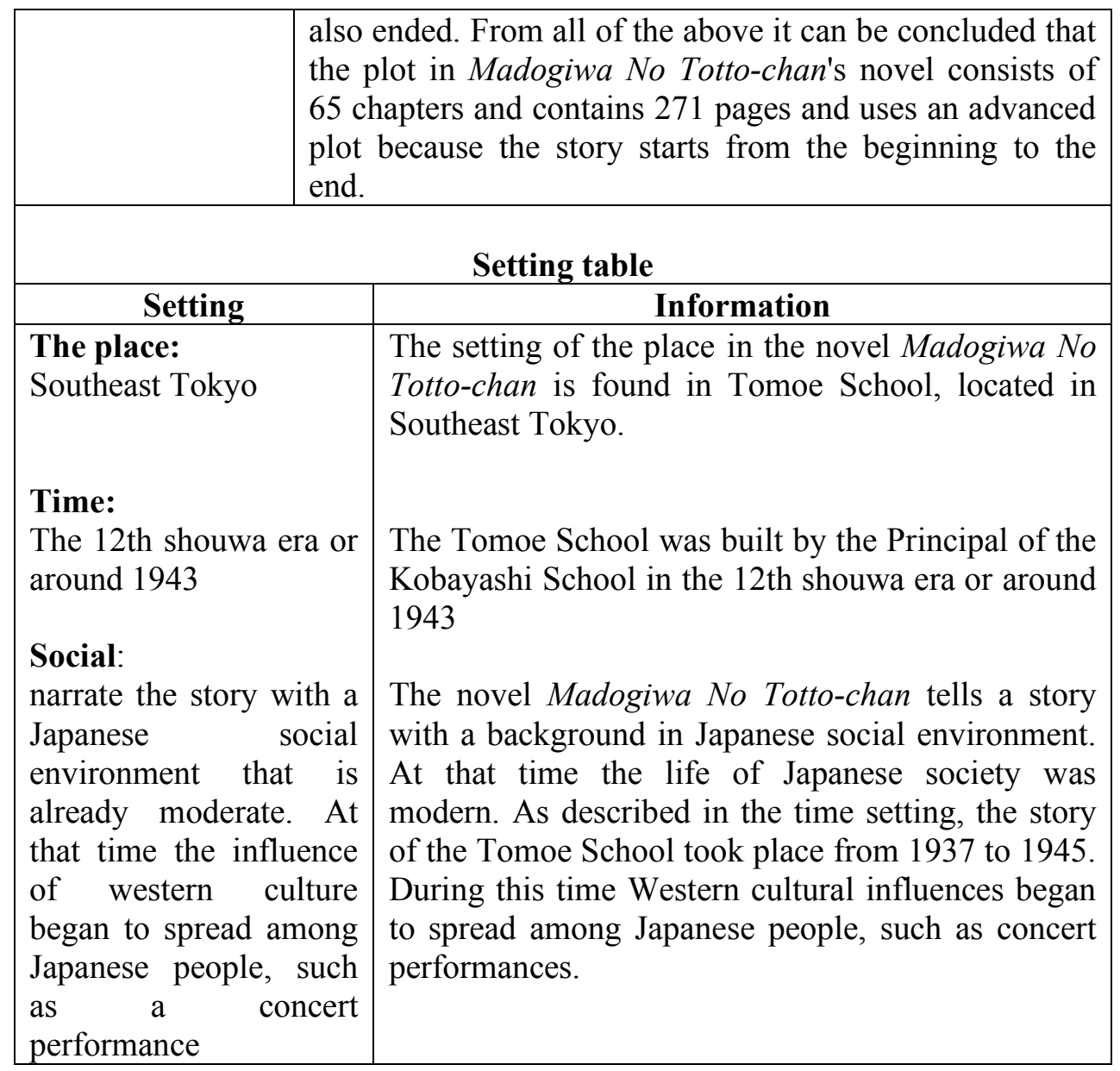

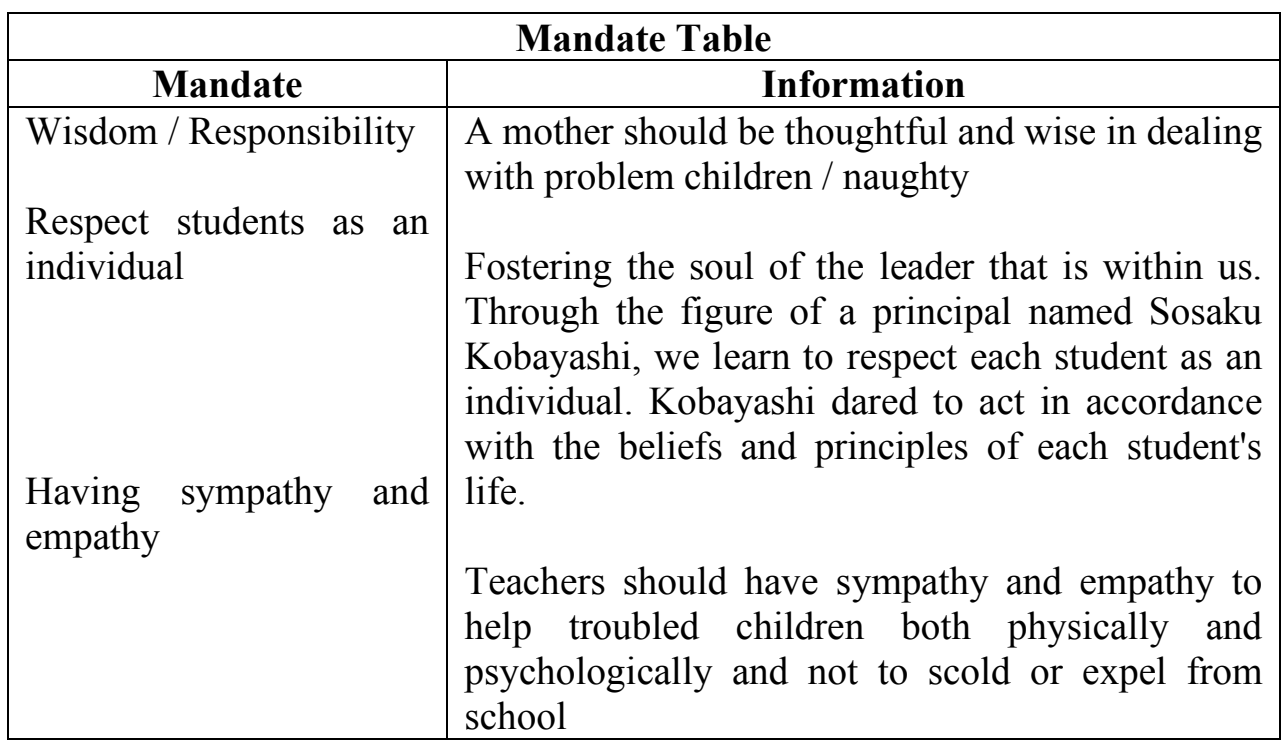


Journal of Educational Method and Technology Vol. 2 No. 2, Agustus 2019

P-ISSN 2622-8459 E-ISSN 2622-8467

http://ejournal.unima.ac.id/index.php/jemtec

Educational Values Table in the Novel Madogiwa No Totto-chan

\begin{tabular}{|c|c|c|}
\hline No & Educational Values & Information \\
\hline 1. & $\begin{array}{l}\text { The Value Character Education } \\
\text { The purpose of character education is to } \\
\text { form good morals if he has in-depth } \\
\text { knowledge of his potential and is able to } \\
\text { realize that potential in his attitude and } \\
\text { behavior. }\end{array}$ & $\begin{array}{l}\text { Independent; } \\
\text { Confidence; } \\
\text { Brave; } \\
\text { Persistent } \\
\text { To be responsible } \\
\text { Humble: } \\
\text { Kind-hearted } \\
\text { Empathy } \\
\text { Creative }\end{array}$ \\
\hline 2. & The Value of Intelligence Education & $\begin{array}{l}\text { Educational Methods } \\
\text { Rhetoric }\end{array}$ \\
\hline 3. & The Value of Social Education & $\begin{array}{l}\text { Respect: } \\
\text { Respect others } \\
\text { Help each other; } \\
\text { Politeness: } \\
\text { Simple: } \\
\text { Forgiving: } \\
\text { Personal who is pleasant } \\
\text { and caring for others: } \\
\text { Be thankful }\end{array}$ \\
\hline 4. & $\begin{array}{l}\text { The Value of National Citizenship } \\
\text { Education }\end{array}$ & $\begin{array}{l}\text { Totto Chan really loves } \\
\text { his country }\end{array}$ \\
\hline 5. & $\begin{array}{l}\text { The Value of Beauty and Aesthetics } \\
\text { Education }\end{array}$ & $\begin{array}{l}\text { Enjoys music; } \\
\text { Learning } \\
\text { experimenting; } \\
\text { Enjoy literature }\end{array}$ \\
\hline 6. & The Value of Physical Education & Sportsmanship \\
\hline 7. & The Value of Religious Education & $\begin{array}{l}\text { Always do good thing } \\
\text { Loves to pray }\end{array}$ \\
\hline 8. & The Value of Family Welfare Education & $\begin{array}{l}\text { Protect } \\
\text { Friendly } \\
\text { Give suggestions as a } \\
\text { form of motivation } \\
\text { Pay attention to student } \\
\text { learning development } \\
\text { Do not have rules that } \\
\text { force and put pressure on } \\
\text { students. } \\
\text { Understand student } \\
\text { interests and talents }\end{array}$ \\
\hline
\end{tabular}


Journal of Educational Method and Technology Vol. 2 No. 2, Agustus 2019

P-ISSN 2622-8459 E-ISSN 2622-8467

http://ejournal.unima.ac.id/index.php/jemtec

\begin{tabular}{|l|l|l|}
\hline & $\begin{array}{l}\text { Providing educative } \\
\text { punishment } \\
\text { Accepting children as } \\
\text { they are }\end{array}$ \\
\hline
\end{tabular}

4. Conclusions And Recommendations

Conclusion

Educational Values are reviewed from the Text Structure in Madogiwa No Totto-Chan's Novel

Madogiwa No Totto-chan's novel is an autobiographical novel written by Tetsuko Kuroyanagi, which tells the story of Kuroyanagi's past, who was fondly called Totto-chan as a child. The experience when he was an elementary school student under the guidance of a school principal and teacher at Tomoe school was built around the 12th year of Shouwa or around 1937. The Tomoe or Tomoe Gakuen school is located in Southeast Tokyo or about three minutes walk from the station Jiyuugaoka on the Toyoko Line. The main characters or main characters are Tottochan and Principal Kobayashi because the intensity of the appearance in Madogiwa No Totto-chan's novel is very prominent and very influential in the story. Main Theme is Education that frees students to be creative, while subtheme: Education must be adjusted to the development of the child's personality The educational values in this novel can be used as examples of learning in schools to help children with problems (naughty, disabled). An educator should be fun and not scold his students because educating children is not with anger but with advice, praise, and trust. Make kids confident, responsible, love each other, and help each other, introduce them to nature because nature stores various sources of knowledge.

\section{Recommendations}

1) For Educators / Teachers

Study of educational values in the Novel Madogiwa No Totto-chan with a qualitative approach can be an alternative learning in schools or colleges because the structure of the novel text is part of the structural approach of Literature, literary sociology and will build creativity in implementing learning, especially in literary teaching skills and the results of this study can be an alternative material in the process of teaching and learning of literary research models of literary texts with literary theory. Through this study students are expected to have a deeper understanding of how they interpret a novel. So it is not only intrinsic elements that are understood by students but they can get to know more about the extrinsic elements that are related to the Poet's educational and life values.

\section{2) For Students}

For students, providing motivation has an appreciation for literary works especially in studying Japanese literature Nihon Bungaku. 
Journal of Educational Method and Technology Vol. 2 No. 2, Agustus 2019

P-ISSN 2622-8459 E-ISSN 2622-8467

http://ejournal.unima.ac.id/index.php/jemtec

\section{References}

Abdurrahman dan Ermanto. The Implementation of Indonesian Literature Appreciation Learning Based on Curriculum (Descriptive Study in Solok District Junior High School Research Report). Padang: IKIP Padang. 1998.

Ahmadi, Mukhsin. 1990. Teaching and Learning Strategies of Language Skills and Literary Appreciation. Malang : YA3 Malang.

Aminuddin, 1990, "Qualitative Methods in Language and Literature Research ", in the Development of Qualitative Research in the Field of Language and Literature." Malang: YA3

Arya, Putu, 1983. Appreciation of Poetry and Prose, Ende Flores: Nusa Indah,

Aspell, Patrick J. 1999. Medievel Western Philosophy: The Europe Emergence. Washington DC: The Council for Researh in Values and Philosophy,

Budianta, Melani, 2002. Reading Literature. Jakarta: Indonesiatera,

Bloomfield, Leonard. 1969. Language. London: George Allen \& Unwin Ltd.

Culler, Jonathan. 1975. Structuralist Poetics : Structuralism Linguistic and the Study of Literature. London : Rontledge \& Kegan Paul,

Davidson Donald . 1978 "What Metaphors Mean." Critical Inquiry Chicago: The University of Chicago Press,

Dianie Abdul Jalil. 1990. Theory and Periodization of Indonesian Poetry. Bandung: Angkasa.

Ducrot, Oswald \& Tzvetan Todov. 1972. Dictionnaire Encyclopé -dique des sciences dulangage. Paris: Seuil.

Eagleton, Terry. 1983. Literary Theory : An Introduction. Minneapolis: University of Minnesota Press,

Effendi, S, 1973. Poetry Appreciation Guidance. Ende Flores, Nusa Indah,

Endraswara, Suwardi. 2006. Research Methodology in Literature. Yogyakarta: pustaka widyatama.

Esten, Mursal, 1990. Ten Instructions for Understanding and Reading Poetry, Padang: Angkasa Raya,

Faruk, 1986. Grounded Methods in Literary Research: An Opening Discussion, Yogyakarta: Makalah PIBSI VIII,

Fokkema, 1977 D.W. and Elrud Kunne-Ibsch. Theories of Literature in the Twentieth Century. London: C. Hurst \& Company.

Fokema, 1998. Twentieth Century Literary Theory, Jakarta: Gramedia Pustaka Umum,

Galisson, R. \& D. Coste, 1976. Dictionnaire de Didactique des Langues. Paris: Hachette.

Jabrohim (ed), 2001. Research Methodology in Literature, Yogyakarta: Hanindita Graha Widia,

James Dickins. 1981 "Models for Metaphor Translation". Target. Cambridge University Press,

James, Hans Robert, 1998. Toward and Aesthetic of Reception, Mineapolis, University of Minnesota Press,

Jassin, HB. 1980. Modern Indonesian Literature in Criticism and Essays. I, II, III, IV. Jakarta: Gramedia,

Jefferson, Ann. 1982 Structuralism and Post Structuralism. Modern Literary Theory: A comparative Introduction. London: Batsford Academic and 
Journal of Educational Method and Technology Vol. 2 No. 2, Agustus 2019

P-ISSN 2622-8459 E-ISSN 2622-8467

http://ejournal.unima.ac.id/index.php/jemtec

Educational Ltd.

Kartodirdjo, Sutomo, 1994. Cultural Development in Historical Perspectives. Yogyakarta: Gajah Mada University Press,

Kerbrat Orrecchioni. 1986. La Connotation.. Lyon: Presse Universitaire de Lyon.

Lakoff, George and Mark Johnson 1980. "Conceptual Methaphor in Everyday Language”, dalam The Journal of Philosophy, Vol 77. No 8 Agustus,

Lakoff, G. \& Mark Johnson. 1980. Metaphors we live by. Chicago \& London: The Univer -sity of Chicago Press.

Lamont, Corliss. 1997. The Philosophy of Humanism (8th edition), New York: Humanist Pres,

Martin, Alex dan Hill Robert, Modern Poetry, London, Longman Group,

Moody, H.L.B. 1981The Teaching of Literature, London: Longman Group, 1981.

Newmark, Peter. 1981. Approaches to Translation. Oxford: pergamon Press,

Nurgiayantoro, Burhan. 2005. Theory of Fiction Studies. Yogyakarta: Gadjah Mada University Press.

Paulo, Freire, 1998. Pedagogy of Freedom: Ethics, Democracy and Civil Courage, New York: Rowman and Littlefield Publisher.

Palmer. 1976. Semantics.. Cambridge: Cambridge University Press.

Perrine, Laurence \& Thomas R. Ar. 1990.Sound and Sense.

Pradopo, Rachmat Djoko. 1990. Poetry Study. Yogyakarta: Gadjah Mada University Press.

Pradopo, Rachmat Djoko. 1990. Indonesian Literature Research. Jakarta: Makalah Kongres Bahasa Indonesia V. Pusat bahasa,

Pradopo. Rachmat Djoko 1995. Some Literary Theories, Critical Methods, and Their Application. Yogyakarta : Pustaka Pelajar.

Ratna, Nyoman Kutha S.U.. 2008 Theories, Methods and Techniques of Literary Research. Yogyakarta : Pustaka Pelajar.

Riffatere, Michael. 1979. Semiotik of Poetry. Bloomington: Indiana Uni versity Press.

Saussure, Ferdinand. 1969. Cours de Linguistique Générale. Paris : Payot.

Semi, Atar, 1990. Indonesian Language and Literature Teaching Design, Bandung: Angkasa,.

Searle. John R. 1997. Expression and Meaning: Studies in the Theory of Speech Acts. Cambridg:

Situmorang, B.P, 1981. Poetry, Theory, Appreciation of Form and Structure, Ende Flores: Nusa Indah,

Sudarsono, Juwono, 1998. Socio-Cultural Reform in the Era of Globalization, Jakarta: Wacha Widia,

Sudijono, Anas. 1998. Introduction to Educational Evaluation. Jakarta: Raja Grafindo.

Supriyadi dkk. 1997. Indonesian Language Education 4. Jakarta:UT..

Suryosubroto. 1997. Teaching and Learning Process in Schools. Jakarta : Rineka Cipta.

Tarigan, Hendry G. 1986. Reading as a Language Skill. Bandung: Angkasa.

Suyitno, 1985. Literature, Values and Exegesis, Jakarta: PT Hanin Data,

Tarigan, Henry Guntur. 1985. Basic Principles of Literature. Bandung. Angkasa,

Teeuw, A. 1983. Reading and Assessing Literature. Jakarta: Gramedia, 
Journal of Educational Method and Technology Vol. 2 No. 2, Agustus 2019

P-ISSN 2622-8459 E-ISSN 2622-8467

http://ejournal.unima.ac.id/index.php/jemtec

Wallace, Robert. 1987. Writing Poems. Boston, Toronto : Little, Brown and Company,

Waluyo, Herman. 1984. Poetry Theory and Appreciation. Jakarta : Erlangga,

Wellek, Rene. 1990. Literary Theory. Jakarta : Gramedia,

Wellek, Rene and Austin Warren. 1990. Theory of Literature, England 